\title{
MENINGKATKAN KEMAMPUAN BINA DIRI MENGENAL RAMBU LALU LINTAS BAGI ANAK TUNAGRHITA SEDANG MELALUI METODE DRIIL DI KELAS VI SDLB-C YPAC MEDAN
}

\author{
Syahril \\ Surel: Syaril23@yahoo.com
}

\begin{abstract}
ABSTRAK
Penelitian ini bertujuan untuk membuktikan bahwa dengan menggunakan metode drill dan media yang bervariasi dapat meningkatkan kemampuan siswa dalam mengenal lambang lalu lintas. Subjek penelitian adalah 11 orang siswa di kelas VI SDLB-C YPAC Medan. Pada waktu observasi hanya 2 orang siswa yang sudah mampu mengenal lambang lalu lintas. Teknik pengumpulan data yang digunakan berupa test dan observasi. Hasil observasi menunjukkan pada siklus I guru (peneliti) sudah dapat menerapkan metode driil dalam pembelajaran bina diri dengan baik (sebanyak 45\%) dan pada siklus II guru (peneliti) dapat menerapkan metode driil dalam pembelajaran bina diri dengan sangat baik (72\%). Pada siklus I aktivitas siswa dikategorikan cukup, sedangkan pada siklus II aktivitas siswa meningkat dan dikategorikan baik.
\end{abstract}

Kata Kunci : Bina Diri, Metode Driil, Rambu Lalu Lintas

\section{PENDAHULUAN}

Dalam rangka mensukseskan sistem pendidikan nasional, pemerintah harus mampu menjamin pemerataan kesempatan pendidikan, peningkatan mutu dan relevansi serta efisiensi manajemen pendidikan. Pemerataan pendidikan diwujudkan dengan program wajib belajar 9 tahun. Program pendidikan berlaku untuk semua warga negara, tidak terkecuali anak luar biasa atau anak berkebutuhan khusus.

SDLB/SLB sebagai salah satu lembaga pendidikan juga berusaha semaksimal mungkin untuk mensukseskan tujuan pendidikan nasional. Berbagai upaya dilakukan untuk peningkatan mutu pendidikan sehingga dapat meng-hasilkan output yang mandiri, tidak tergantung kepada masyarakat, dan bisa turut berperan dalam pembangunan. Salah satu faktor yang mendukung keberhasilan pendidikan adalah dengan menyelenggarakan kegiatan pembelajaran yang berkualitas. Kegiatan pembelajaran dikatakan berhasil jika siswa dapat menguasai tujuan pembelajaran. Banyak hal yang dapat mempengaruhi keberhasilan pembelajaran, diantaranya adalah kemampuan guru dalam merencanakan dan melaksanakan pembelajaran. Selain itu guru juga harus memperhatikan keunikan masing-masing siswanya sehingga siswa dapat menerima pelajaran sesuai kemampuan yang dimilikinya dengan kondisi masingmasing. Dengan demikian siswa dapat menerima dan menguasai materi pembelajaran secara tuntas sesuai yang diharapkan oleh guru.

Salah satu contoh pembelajaran yang harus dimiliki 
oleh anak tunagrahita adalah bina diri keterampilan beradaptasi dengan lingkungan yang disampaikan lewat Kompetensi Dasar peraturan lalu lintas dengan materi ajar mengenal rambu-rambu lalu lintas. Keselamatan berlalulintas adalah kebutuhan yang harus dilatih sejak dini kepada anak-anak. Mengenai hal-hal yang harus dilakukan dan harus dihindari atau dilarang dalam berlalu lintas adalah menandai kecintaan kepada lalulintas, yang merupakan bekal bagi anak-anak untuk bisa beradaptasi dengan lingkungannya dan tinggal bersama masyarakat serta tidak tergantungan pada orang lain dengan kata lain untuk melatih anak mendiri.

Rambu lalu lintas salah satu alat kelengkapan jalan dalam bentuk tertentu yang membuat lambang, huruf, angka, kalimat, atau perpaduan antaranya yang digunakan untuk mamberi peringatan, larangan, perintah dan petunjuk bagi pemakai jalan.

Semoga dengan mengenali arti dari rambu-rambu lalu lintas kita dapat berprilaku tertip dijalan raya. Rambu lalulintas dibuat untuk kenyamanan para pengguna jalan, Kita semua sudah seharusnya mematuhi rambu-rambu tersebut baik ada petugas maupun tidak ada petugas agar keselamatn pengguna jalan dapat terlindungi dengan baik.

Anak tunagrahita sebagai anak pada umumnya memiliki hak dan kebutuhan untuk berkembang atau mengaktualisasikan potensi yang ada pada dirinya sehingga mereka dapat hidup mandiri dan tidak terlalu bergantung pada orang lain. Namun pemenuhan hal-hal tersebut diatas anak tunagrahita mengalami hambatan karena keterbatasan fungsi kecerdasan intelektualnya yang berada di bawah usia kronologisnya secara signifikan. Karena itu anak tunagrahita memperlihatkan aktualisasi fungsi intelektualnya, kemampuan dalam prilaku adaptif di bawah usianya, dan termanifestasi dalam masa perkembangannya.

$$
\text { Sebagai akibat dari }
$$

kekurangan yang dimilikinya maka anak tunagrahita memiliki ciri-ciri khusus, permasalahan dan kebutuhan yang tentu saja memerlukan layananan khusus pula agar Ia dapat berkembang seoptimal mungkin sehingga akhirnya layak dimasyarakat. Ciri-ciri khusus (karakter khas), anak tunagrahita seperti; sulit mempelajari hal-hal yang abstrak, miskin pengalaman, miskin konsentrasi, cepat lupa, kurang mampu mengikuti petunjuk, membutuhkan waktu belajar yang lama, miskin pertimbangan, kurang inisiatif, kurang mampu memelihara kesehatan, kurang koordinasi motorik, dan yang lain-lain. Sebagai akibat dari hal-hal tersebut Ia mengalami kesulitan belajar diantaranya melalui pengamatan. Karena itu menolong diri dan megurus diri serta merawat diri dia mengalami kesulitan.

Upaya pelayanan dan rehabilitasi sosial diarahkan agar 
penyandang tunagrahita mampu melaksanakan fungsi sosialnya dalam kehidupan bermasyarakat. Program latihan mengurus diri sendiri memiliki peran sentral dalam mengantarkan peserta didik dalam melakukan kegiatan untuk dirinya sendiri. Melalui latihan mengurus diri sendiri pada pelajaran Bina Diri diarahkan untuk mengaktualisasikan mengembangkan kemampuan peserta didik dalam melakukan aktivitas hidup sehari-hari untuk kebutuhan dirinya sendiri sehingga mereka tidak membebani orang lain.

Bina Diri mengacu pada suatu kegiatan yang bersifat pribadi, tetapi memiliki dampak dan berkaitan dengan human relationship. Disebut pribadi karena mengandung pengertian bahwa keterampilanketerampilan yang diajarkan atau dilatihkan menyangkut kebutuhan individu yang harus dilakukan sendiri tanpa dibantu oleh orang lain bila kondisinya memungkinkan.

Beberapa istilah yang biasa digunakan untuk menggantikan istilah bina diri yaitu "Self Care", "Self Help Skill",atau "Personal (Casmini, 2008; 2). Sedangkan Chita (2011) menyatakan bahwa Bina Diri merupakan serangkaian kegiatan pembinaan dan latihan yang dilakukan oleh guru yang profesional dalam pendidikan khusus, secara terencana dan terprogram terhadap individu yang membutuhkan layanan khusus, yaitu individu yang mengalami gangguan koordinasi gerak-motorik, sehingga mereka dapat melakukan aktivitas kehidupan sehari hari, dengan tujuan meminimalisasi dan atau menghilangkan ketergantungan terhadap bantuan orang lain dalam melakukan aktivitasnya.

Salah satu kompetensi dalam kurikulum pembelajaran Bina Diri pada aspek mengurus diri sendiri adalah melaksankan orientasi dengan lingkungan dengan materi pokok peraturan lalu lintas. Misalnya pada kegiatan pembelajran mengenal rambu rambu lalulintas, kedengarannya sangat sederhana tapi bila diaplikasikan pada anak tungrahita, kemungkinan sebagian besar dari mereka tidak bisa melakukan sendiri tanpa diajarkan dan dilatih terlebih dahulu.

Proses belajar mengajar merupakan suatu proses yang mengandung serangkaian aktivitas guru dan siswa atas dasar timbal balik yang berlangsung dalam pembelajaran untuk mencapai tujuan tertentu. Selama peneliti menjadi guru kelas VI SDLB YPAC Medan banyak sekali menghadapi permasalahan dalam kegiatan pembelajaran. Hal yang meresahkan adalah hasil belajar siswa yang tidak mencapai tujuan yang diharapkan.

Dalam kesempatan ini peneliti berfokus pada pembelajaran kemampuan bina diri. Pembelajaran kemampuan bina diri dengan Kompetensi melaksanankan orientasi lingkungan dengan materi mengenal rambu-rambu lalu lintas pada siswa kelas VI bagian tunagrahita sedang 
semester I tahun pelajaran 2013/2014 di SDLB-C YPAC Medan hasilnya sangat memprihatinkan. Dari 11 orang siswa yang diobservasi hanya 3 orang yang bisa menjawab pertanyaan yang di berikan dan mendapatkan nilai 7 , sedangkan 8 siswa lainnya mendapat nilai dibawah 6. Dari nilai yang diperoleh siswa tersebut menunjukan bahwa hasil belajar siswa sangat rendah dan tujuan pembelajaran tidak tercapai untuk Kompetensi Dasar Mampu beradaptasi dilingkungan dan Standar Kompetensi Melaksanakan orientasi lingkungan dengan materi peraturan lalu lintas pada kegiatan pembelajaran mengenal rambu-rambu lalu lintas.

Untuk mengetahui penyebab rendahnya hasil belajar siswa tersebut, peneliti meminta teman sejawat dalam hal ini ibu Ade Sihombing yang kelasnya relevan dengan kelas peneliti sendiri untuk mengidentifikasi permasalahan atau kekurangan dalam pelaksanaan kegiatan pembelajaran. Dari hasil pengamatan dan diskusi, terungkap bahwa 8 siswa yang mendapat nilai rendah tersebut mengalami beberapa masalah dalam kegiatan pembelajaran.

Permasalahan yang timbul saat pembelajran diberikan dapat diidentifikasi antara lain adalah : (a). kurangnya minat belajar pada siswa, (b). penjelasan guru masih bersifat abstrak,(c.) penggunaan media/alat peraga kurang tepat dan kurang optimal (d). metode yang digunakan kurang bervariasi, (e). siswa kurang diajak berpartisipasi dalam kegiatan pembelajaran.

Berdasarkan permasalahan tersebut, maka peneliti melakukan penelitian tindakan kela dengan judul "Meningkatkan Kemampuan Bina Diri Mengenal Rambu Lalu Lintas Bagi Anak Tunagrahita Sedang Melalui Metode Drill di kelas VI Semester I SDLB-C YPAC Medan tahun Pelajaran 2013/2014".

\section{METODE PENELITIAN}

Praobservasi dilaksanakan Agustus 2013. kegiatan ini dilakukan pengenalan lapangan dan identifikasi terhadap masalah.

Jenis penelitian yang dilakukan dalam penelitian ini adalah Penelitian Tindakan Kelas (PTK) dengan berkolaborasi dengan teman sejawat. Penelitian ini dilaksanakan di kelas VI SDLB-C YPAC Medan tahun pelajaran 2013/2014. Subjek dalam penelitian ini adalah 11 orang siswa yaitu 8 laki-laki \& 3 perempuan sebanyak 33 orang siswa. Penelitian ini berbentuk siklus yang terdiri dari empat tahapan, yaitu: 1). Perencanaan, 2). Pelaksanaan, 3). Pengamatan dan 4). Refleksi.

\section{HASIL DAN PEMBAHASAN Siklus I}

Kegiatan penelitian ini dilaksanakan mulai dari perencanaan, pelaksanaan tindakan, evaluasi dan refleksi. 


\section{Perencanaan}

Pada tahap perencanaan ini meliputi identifikasi, perumusan masalah dan analisis masalah.

\section{a. Identifikasi Masalah}

Berdasarkan dari hasil pengamatan dan pengalaman peneliti selama mengajar siswa tunagrahita yang belum mampu mengenal lambang/simbol rambu-rambu lalu lintas. Pada umumnya siswa tunagrahita sedang memang tergantung moodnya jika tidak lagi mood untuk belajar anak susah untuk konsentrasi untuk menerima pembelajaran yang diberikan dengan demikian seorang guru harus mencobakan beberapa metode yang dapat meningkat motivasi belajar siswa dan begitu juga dengan media yang cocok dengan siswa.

Berdasarkan deskripsi situasi tersebut maka dapat diidentifikasikan masalah yang berkaitan dengan meningkatkan kemampuan mengenal rambu-rambu lalu lintas bagi anak tuna grahita sedang melalui metode drill pada kelasVI SDLB-C YPAC Medan adalah sebagai berikut: Apakah dengan metode Drill dapat meningkatkan kemampuan bina diri mengenal rambu-rambu lalu lintas bagi siswa tunagrahita sedang pada siswa kelas VI semester I SLBC YPAC Medan?

\section{b. Perumusan masalah}

"Meningkatkan kemampuan bina diri mengenal rambu-rambu lalu lintas bagi anak tunagrahita sedang melalui metode drill pada kelas VI SDLB-C YPAC Medan".

\section{c. Analisis masalah}

Pertanyaan yang muncul pada perumusan masalah di atas dapat dijadikan alat untuk menganalisis kelemahan-kelemahan pada proses belajar mengajar yang telah dilaksanakan oleh guru, terutama dari metode pengajaran. Metode pengajaran yang selama ini sering digunakan guru adalah dengan tradisional yaitu dengan menggunakan ceramah, pemberian tugas sehingga anak tidak merasa tertarik untuk belajar dan bahkan anak merasa terpaksa untuk belajar. Tetapi setelah peneliti mencoba dengan metode Drill dengan memberikan latihan yang berulangulang dan kontinu dari kelas, kelingkungan sekolah sampai ke jalan raya secara berulang-ulang siswa termotivasi untuk belajar karena mereka merasa senang dan tidak merasa terbeban sedang belajar sebagaimana kita ketahui anak tuna grahita sedang mempunyai memori yang pendek maka dalam mengajarkan sesuatu harus secara berulang-ulang dan siswa tuna grahita tidak suka dengan situasi yang serius dan membosankan.

\section{d. Penentuan jadwal dan skenario pelaksanaan tindakan}

Peneliti dan kolaborator menyusun prosedur jadwal dan skenario tindakan jumlah pertemuan disesuaikan dengan program yang 
sudah ditentukan dengan tema kompetensi dasar mengenal ramburambu lalu lintas.

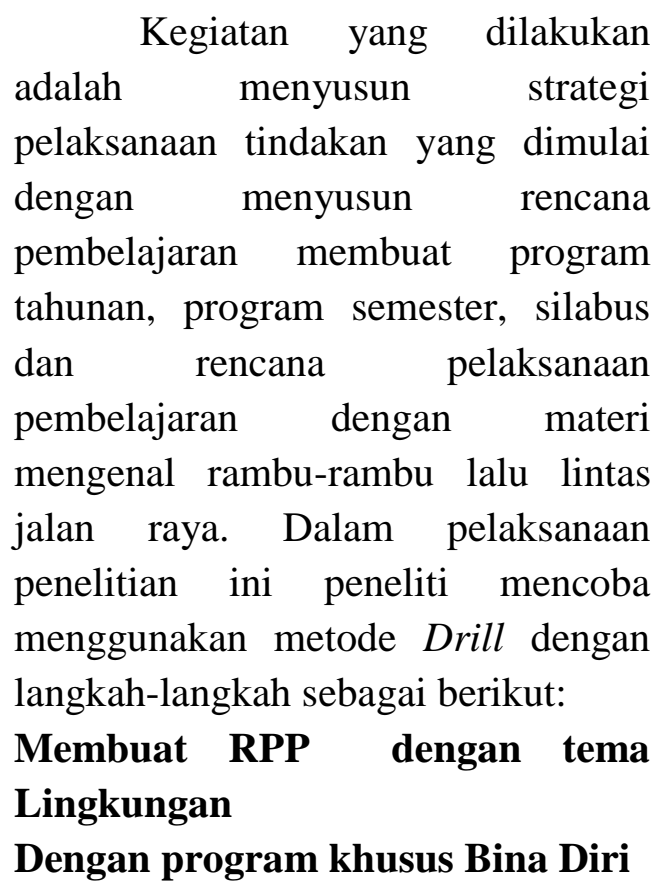

5.Standar Kompetensi : Mampu bradaptasi di lingkungan

5.1 Kompetensi Dasar : Peraturan lalu lintas

Indikator :

5. 1.1.Menyebutkan simbol atau gambar rambu-rambu lalu lintas jalan raya

5.1.2. Meyebrang jalan dengan benar

5.1.3. Mematuhi peraturan lalu lintas

\section{Pelaksanaan Tindakan di}

\section{Lingkungan Sekolah}

Pada pelaksanaan tindakan ini kegiatan yang dilakukan peneliti adalah :Menyiapkan media yang diperlukan untuk pelaksanaan mulai dari kegiatan awal sampai kegiatan akhir, dapat dilihat dalam RPP secara terpisah yaitu mengenal simbol rambu-rambu lalu lintas, menyebrang dengan benar memahami arti lalu lintas sesuai gambar dan membedakan lambang rambu lalu lintas sehingga siswa tuna grhita sedang mampu beradaptasi dengan lingkungan. Mengkondisikan siswa untuk dibawa kehalaman sekolah, dan mencari tempat latihan yang cocok dan sesuai dengan kondisi siswa.

Berdasarkan perbaikan yang dilakukan guru untuk meningkatkan kemampuan mengenal rambu lalu lintas bagi anak tunagrahita sedang di kelas VI SDLB-C YPAC Medan adalah sebagai berikut:

1. Terutama pengelolaan kelas penting untuk pelaksanaan pembelajaran, disamping itu guru juga harus bisa mengelola siswa agar siswa bisa mengikuti pembelajaran semestinya bisa menerima pembelajaran sewaktu proses belajar mengajar berlangsung di dalam kelas sesuai dengan indikator yang kita harapkan. Dalam pembelajaran kita mengharapkan anak merasa senang dalam belajar dan tidak merasa terpaksa untuk belajar karna kita ketahui anak ini disamping IQ dibawah normal juga hiperaktif. Namun dalam kegiatan ini belum semua anak yang mau aktif dan tenang dalam menerima pembelajaran yang diberikan guru.

2. Saat pembelajaran dikelas anakanak masih kurang termotivasi untuk belajar dengan baik, masih banyaknya anak yang kurang bergairah untuk belajar dan masih menggangu teman dan asyik 
bermain sendiri, dalam belajar belum begitu terdapat kemajuan.

Pemantauan dilakukan oleh pengamat untuk memantau segala aktivitas yang dilakukan guru maupun anak pada waktu siklus 1 . Berdasarkan hasil penilain terhadap kemampuan mengenal rambu-rambu lalu lintas yang dilakukan dengan berulang-ulang memakai metode latihan (Drill) diketahui mengalami peningkatan dibandingkan dengan praobservasi.Sewaktu menerima pembelajaran dikelas pada siklus 1 sebagai terlihat pada gambar diketahui mengalami peningkatan jika dibandingkan dengan pra sebelumnya.

Hasil penilaian dari siklus 1 terlihat pada setiap guru memberikan pembelajaran di kelas siswa sudah bersemangat dan lebih serius untuk belajar dan siswa sudah banyak yang mengenal dan mengerti lambang rambu lalu lintas yang ada pada gambar yang ditunjukkan guru sewaktu proses belajar mengajar baik di kelas maupun dilingkungan sekolah seperti yang terlihat pada gambar. Pada tahap observasi hanya 2 orang saja yang sudah mengenal rambu lalu lintas yaitu oriza dan rizki. Dan pada tahap siklus I ini sudah menjadi 5 orang dari 11 siswa yang di latih, yaitu Oriza, Riski, Mutia, Wahyu dan Andre. Hal ini memang sudah mengalami peningkatan tapi belum seperti yang diharapkan.

\section{Observasi}

Observasi dilakukan selama siklus I dilaksanakan. Data observasi direkam dengan menggunakn daftar cek dan catatan terbuka serta dibantu dengan kamera. Perilaku anak yang selama ini dalam menerima pembelajran kurang termotivasi dan konsentrasi, selalu berpindah-pindah tempat walaupun pembelajaran sedang berlangsung, karna mereka tidak berminat untuk belajar dan membosankan selama siklus I anak sudah nampak senang dan sudah termotivasi untuk belajar.

Disamping memberikan

penilaian tentang kemampuan mengenal rambu-rambu lalu lintas peneliti juga menjejaki tentang tingkah laku siswa dalam belajar. Berdasarkan pengamatan peneliti pada siklus 1. Pada umumnya belum nampak sekali perubahan yang ada pada siswa karena disebabkan situasi belajarnya masih di dalam kelas dan lingkungan sekolah sehingga anak nampak masih merasa bosan dengan lingkungan yang itu-itu aja. Dan peneliti pada siklus II ini akan membawa anak kepada suasana yang sesungguhnya dimana terdapat dan terjadinya pristiwa rambu lalu lintas itu digunakan peneliti juga sudah mulai percaya kepada siswa untuk diajak kejalan raya setelah dilakukan latihan yang berulang-ulang pada siklus I. Observasi ini dilakukan peneliti juga kolaborator dengan guru lain yaitu guru bidang studi olah raga dalam hal ini Bpk. Ahmandi Malaon. 


\section{Refleksi}

Selama tindakan dilaksanakan pada siklus 1, peneliti dan kolaborator mengetahui bahwa pada umumnya kemampuan siswa dalam mengenal rambu-rambu lalu lintas jalan raya masih kurang dan belum seperti harapan yang diinginkan. Dan tingkahlaku anak dalam menerima pembelajran di kelas sudah menunjukkan tingkah yang baik. Setelah diadakan refleksi terhadap tindakan yang diberikan tampak ada beberapa hal yang perlu diperbaiki dan ditingkatkan.

Kelemahan-kelemahan yang ada seperti masih banyak siswa yang belum mampu untuk memahami dan membedakan rambu-rambu lalu lintas dan tidak bisa duduk dengan tenang dan bermain-main dengan teman sebelahnya sehingga mereka kurang motivasi untuk belajar. Berdasarkan hasil tersebut, diputuskan untuk memperbaiki tindakan yang telah dilaksanakan yakni lebih memfokuskan perbaikan-perbaikan kelemahan yang terdapat pada siklus 1.

Untuk memperbaiki atau meningkatkan kemampuan siswa dalam mengenal rambu-rambu lalu lintas jalan raya disamping tetap mengunakan metode driil peneliti akan membawa siswa ke arah yang sesungguhnya yaitu ke jalan raya dengan lambang lalu lintas yang sesungguhnya dengan memberikan latihan di jalan raya peneliti berharap dapat meningkatkan kemampuan siswa dalam mengenal rambu-rambu lalu lintas jalan yang ada. Pada siklus ke II ini peneliti membawa anak ke jalan raya agar pengetahuan mereka semakin meningkat dan mempunyai pengalaman dalam belajar yang sesungguhnya agar mereka kelak juga tidak tergantung kepada orang lain.

\section{Pembahasan Hasil Siklus I}

Kesimpulan dari pada siklus 1 ditunjukkan untuk menjawab masalah penelitian yang telah dirumuskan sebelumnya (Apakah dengan metode drill dapat meningkatkan kemampuan mengenal rambu-rambu lalu lintas bagi anak tuna grahita sedang di kelas VI SLB-C YPAC Medan?) akan di teliti pada siklus ke II ini.

\section{Siklus ke II}

Kegiatan penelitian ini dilaksanakan mulai dari perencanaan, pelaksanaan tindakan masalah dan analisis masalah.

\section{Perencanaan}

Pada tahap perencanaan ini meliputi identifikasi, perumusan masalah dan analisis masalah.

\section{a. Identifikasi Masalah}

Berdasarkan dari hasil pengamatan dan pengalaman peneliti selama sikus I siswa tunagrahita masih belum mampu mengenal rambu-rambu lalu lintas terutama, mengenal, memahami arti atau makna lambang dan membedakan ramburambu lalu lintas hanya beberapa orang siswa saja yang bisa mengenal lambang rambu lalu lintas. Pada 
umumnya siswa tunagrahita sedang memang tergantung moodnya jika tidak lagi mood untuk belajar anak susah untuk konsentrasi untuk menerima pembelajran yang diberikan dengan demikian seorang guru harus mencobakan beberapa metode yang dapat meningkat motivasi belajar siswa dan begitu juga dengan media yang cocok dengan siswa.

Berdasarkan deskripsi situasi pada siklus 1 maka dapat diidentifikasikan masalah yang berkaitan dengan meningkatkan kemampuan mengenal rambu-rambu lalu lintas bagi anak tunagrahita sedangmelalui metode drill di kelas V I SDLB-C YPAC Medan adalah sebagai berikut:

Apakah dengan metode drill dapat meningkatkan kemampuan mengenal rambu-rambu lalu lintas bagi siswa tunagrahita sedang dengan media jalan raya pada siswa kelas VI SDLB-C YPAC Medan?

\section{b. Perumusan masalah}

Meningkatkan kemampuan mengenal rambu-rambu lalu lintas bagi anak tunagrahita sedang melalui metode drill melalui media jalan raya?

\section{c. Analisis masalah}

Pertanyaan yang muncul pada perumusan masalah di atas dapat dijadikan alat untuk menganalisis kelemahan-kelemahan pada proses belajar mengajar yang telah dilaksanakan oleh guru pada siklus I, terutama situasi belajar di dalam kelas akan diperbandingkan dengan pembelajaran di jalan raya dengan metode drill pada siklus I berada di kelas dan lingkungan sekolah belum nampak begitu peningkatan kemampuan siswa yang diharapkan dalam indikator pembelajaran mengenal rambu-rambu lalu lintas. Maka dalam siklus II inipeneliti akan membawa siswa ke arah situasi yang sebenarnya dan yang sangat menantang yaitu jalan raya.

\section{d. Penentuan jadwal dan skenario pelaksanaan tindakan}

Peneliti dan kolaborator menyusun prosedur jadwal dan skenario tindakan jumlah pertemuan disesuaikan dengan program yang sudah ditentukan dengan tema kompetensi dasar mengenal ramburambu lalu lintas

Kegiatan yang dilakukan adalah menyusun strategi pelaksanaan tindakan yang dimulai dengan menyusun rencana pembelajaran membuat program tahunan, program semester, silabus dan rencana pelaksanaan pembelajaran yang berkompetensi dasar mengenal rambu-rambu lalu lintas. Dalam pelaksanaan penelitian ini peneliti mencoba menggunakan metode drill dan media jalan raya dengan langkah-langkah sebagai berikut: 


\section{Perencanaan}

\section{Membuat RPP dengan tema Lingkungan Dengan program khusus Bina Diri}

5.Standar Kompetensi : Mampu bradaptasi di lingkungan

5.1 Kompetensi Dasar : Peraturan lalu lintas

Indikator :

5.1.1. Menyebutkan simbol atau gambar rambu-rambu lalu lintas jalan raya

5.1.2. Meyebrang jalan dengan benar

5.1.3. Mematuhi peraturan lalu lintas

\section{Pelaksanaan Tindakan di jalan Raya}

1) Pada pelaksanaan tindakan ini kegiatan yang dilakukan peneliti adalah Menyiapkan rancangan kegiatanyang diperlukan untuk pelaksanaan mulai dari kegiatan awal sampai kegiatan akhir, dapat dilihat dalam RPP.

2) Menyiapkan mental anak dan memberikan peraturan-peraturan di jalan raya.

Berdasarkan upaya perbaikan yang dilakukan peneliti dalam pembelajaran dengan kompetensi dasar melaksanakan orientasi lingkungan dengan materi pokok peraturan lalu lintas dalam kegiatan mengenal rambu-rambu lalu lintas jalan raya pada kelas VI SDLB-C YPAC Medan. Pada siklus II ini sebagai penelitian terhadap peningkatan mengenal rambu-rambu lalu lintas dengan lokasinya langsung terjun ke jalan raya sudah mengalami peningkatan kearah yang lebih baik yang biasanya siswa tidakmampu untuk menganal lambang rambu lalu lintas dengan baik sudah hampir semua siswa mampu mengenal lambang rambu lalu lintas dan sebagian besar sudah mengerti artinya dan membedakan lambang tersebut hannya tinggal tiga orang anak saja yang belum mengerti yang disebabkan IQnya sangat rendah dan sering libur saat diberikan pelatihan. Dari 11 siswa kels VI yang sudah mengalami peningkatan sebanyak 8 orang yang mengalami peningkatan kemampuan mengenal rambu lalu lintas sudah mencapai $72 \%$ keberhasilan peningkatan mengenal lalu lintas dibandingkan dengan siklus pertama $45 \%$ yang mampu mengenal lalu lintas.

\section{Observasi}

Observasi dilakukan selama tindakan berlangsung dengan menggunakn lembar pengamatan aktivitas dalam mengikuti pembelajaran di jalan raya, observasi dilakukan peneliti dengan kolaborasi.

Hasil observasi/pengamatan yang diperoleh berdasarkan catatan diuraikan sebagai berikut:

Pelaksanaan pembelajaran pada siklus ke II terlaksana dengan baik dengan waktu yang ditentukan $6 \mathrm{x}$ pertemuan $2 \times 30$ menit sekali putaran. Siswa menunjukkan aktivitas yang baik dengan arti kata termotivasi dan bersemangat serta merasa senang melakukan latihan yang diberikan guru . 
Suasana di jalan raya mencerminkan kegembiraan tersendiri bagi siswa karana siswa sudah tidak merasa terbebani dalam belajar seolah-olah merasa bermain main di jalan raya, namun masih ada 3 orang siswa saja yang masih belum pengalami peningkatan kemampuan mengenal rambu lalu lintas. Hasil tes didapat sebanyak 8 orang siswa sudah mendapatkan nilai 7 ke atas hanya 3 orang siswa yang nilainya di bawah 6.

\section{Refleksi}

Hasil perubahan yang diperoleh sebagai indikator tindakan menunjukkan peningkatan untuk semua jenis aktivitas belajar siswa khususnya dalam bina diri mengenal rambu-rambu lalu lintas bagi siswa tunagrahita sedang melalui metode drill di kelas VI SDLB-C YPAC Medan sudah mengalami peningkatan kemampuan dalam beradaptasi dengan lingkungan dalam hal ini mengenal rambu-rambu lalu lintas mengalami peningkatan jika dirataratakan sekitar $72 \%$ sudah tercapai.

Selanjutnya keterampilan guru dalam penggunaan komunikasi dalam pembelajaran meningkat. Timbul rangsangan-rangsangan serta kesabaran dan ketelatenan dalam menghadapi siswan seperti mengajak anak dengan lembut. Kesabaran menghadapi anak meningkat. Memberikan kasih sayang yang seimbang. Melatih siswa bertanggung jawab.

\section{Pembahasan Hasil siklus II}

Kesimpulan dari kegiatan peneliti pada pelitian pada siklus ke II ini diuraikan sebagai berikut:

Pada umuimnya pembelajaran sudah berjalan dengan baik, sebagian besar kemampuan bina diri mengenal rambu-rambu lalu lintas siswa sudah mengalami peningkatan sesuai harapan menunjukkan peningkatan kearah yang lebih baik, dalam belajar sudah nampak siswa merasa senang, aktif dan punya motivasi untuk mengerjakan latihan-latihan yang diberikan oleh guru saat menerima pembelajaran baik di kelas maupun di jalan raya.

Guru/peneliti bersemangat untuk mengajar karena mengalami perubahan walaupun masih adanya anak yang belum mengalami perubahan. Tetapi guru/peneliti berusaha memotivasi siswa agar semua dapat termotivasi dalam belajar. Meningkatkan kemampuan siswa dalam bina diri menganal rambu-rambu lalu lintas akan dapat berubah ke arah yang lebih baik bila dilakukan perbaikan secara terus menerus dan kontinuitas.

\section{KESIMPULAN}

Setelah dilakukan pengamatan dan analisis dalam penelitian diperoleh beberapa kesimpulan antara lain :

Penggunaan metode drill dan media yang bervariasi dalam pembelajarn bina diri mengenal rambu-rambu lalu lintas pada siswa tunagrahita sedang melalui metode drill pada kelas IV 
SDLB-C YPAC Medan mengalami peningkatan ke arah yang lebih baik, dan dapat meningkatkan motivasi anak untuk belajar di dalam kelas maupun diluar kelas. Hal ini dapat dilihat dari tiga indikator yaitu: (1). Adanya peningkatan dalam mengenal lambang rambu lalu lintas (2). Adanya peningkatan memahami arti dan makna lambang lalu lintas (3). Sudah bisa membedakan lambang yang terdapat pada rambu-rambu lalu lintas, dapat digambarkan sebagai berikut sewaktu peneliti ditahap observasi hanya 2 orang siswa yang mampu mengenal lambang ramburambu lalu lintas $18 \%$ sedangkan pada siklus pertama sebelum diberikan perlakuan atau disebut dengan tahap Baseline mengalami peningkatan kemampuan kearah yang lebih baik dimana jumlah siswa yang mampu mengenal rambu lalu lintas, memahami arti lambang, dan membedakan lambang menjadi 5 orang siswa sekitar $45 \%$ kemudian dilanjutkan dengan siklus ke II dan di sebut juga dengan tahap Intervensi tahap setelah diberikan perlakuan dengan metode drill dan medianya jalan raya kemampuan siswa dalam mengenal rambu lalu lintas, memahami arti lambang lalu lintas dan membedakan lambang lalu lintas menjadi 8 orang orang siswa atau $72 \%$ dari jumah siswa yang terlibat dalam peneitian.

Berdasarkan hasil prosentase di atas, anak mengalami peningkatan kemampuan bina diri mengenal rambu-rambu lalu lintas. Siswa merasa sudah nampak termotivasi untuk belajar dan menunjukkan peningkatan kemampuan kearah yang diharapkan sesai dengan indikator pembelajaran.

Berdasarkan hasil penelitian, pembahasan dan kesimpulan seperti yang telah diuraikan di atas, maka peneliti menarik kesimpulan sebagai berikut:

1. Hendaknya para guru khususnya guru SLB-C senantiasa mencari metode yang cocok dengan karakteristik anak yang diajarkan sehingga proses belajar mengajar yang menyenangkan dapat tercipta dengan baik.

2. Metode drill dengan media yang bervariasi dalam proses belajar mengajar hendaknya diterapkan kepada siswa tunagrahita sedang agar untuk melatih kemampuan dalam bidang akademik maupun bina diri.

3. Kami sebagai seorang guruberharap ke pada lembaga pendidikan agar selalu memotivasi guru untuk meningkatkan kemampuan keprofesionalisnya dengan jalan memberikan pelatihan-pelatihan untuk peningkatan mutu pendidikan terutama pendidikan khusus dimasa yang akan datang.

\section{DAFTAR RUJUKAN}

Arikunto, Suharsimi. 2007. Prosedur Penelitian

Pendekatan Praktik. Jakarta: Bumi Aksara. 
Amin, Moh. 1995. Ortopedagogik Anak Tunagrhita. Jakarta: Persen Perguruan Tinggi.

Astati. 1995. Program Khusus Bina Diri Biakah Aku Mandiri. Jakarta: DEPDIKNAS.

Brata, Surya 1995. Psikologi Pendidikan. Jakarta: Raja Grafindo Persada.

Bosono, Mardiyati. 1998. Diagnosis dalam Pendidikan. Jakarta: Depdikbud.

Casmini, Mimin. 2008. Pengajaran Bina Diri dan Bina Gerak. Bandung: Rineka Cipta.

Chinta, Silviana. 2011. Bina Diri bagi Anak Tunagrahita, tersedia pada http.com/2011/09/bina diri Tunagrahita. Html diakses pada tanggal 16 April 2012.

Depdikbud. 1977. Kurikulum Pendidikan Luar Biasa: Jakarta: Depdikbud.

Rahman, Saiful. 2003. Pendidika Luar Biasa. Jakarta: Depdiknas.

J. Mariah, Wantah. 2007. Pengembangan Kemandirian Anak Tunagrahita Матри Latih. Jakarta: Depdiknas.

Mampuniarti. 2007. Pendekatan Pembelajaran bagi Anak "Tunagrahita Hambatan
Mental. Yogjakarta: Kanva Publisineer.

Iskandar. 2008. Metodologi Penelitian Sosial (Kuantitatif dan Kualitatif. Jakarta: Gaung Persada Press. 